\title{
Al-Hf-Zr (Aluminum-Hafnium-Zirconium)
}

\section{Raghavan}

Recently, [2010Rok] determined the phase equilibria in Al-rich alloys of this ternary system between 600 and $400{ }^{\circ} \mathrm{C}$.

\section{Binary Systems}

The Al-Hf system [1998Mur] depicts a number of intermediate phases: $\mathrm{Hf}_{2} \mathrm{Al}\left(\mathrm{Cl}, \mathrm{CuAl}_{2}\right.$-type tetragonal), $\mathrm{Hf}_{3} \mathrm{Al}_{2}\left(\mathrm{Zr}_{3} \mathrm{Al}_{2}\right.$-type tetragonal), $\mathrm{Hf}_{4} \mathrm{Al}_{3}\left(\mathrm{Zr}_{4} \mathrm{Al}_{3}\right.$-type hexagonal), $\mathrm{HfAl}\left(B_{f}, \mathrm{CrB}\right.$-type orthorhombic), $\mathrm{Hf}_{2} \mathrm{Al}_{3}\left(\mathrm{Zr}_{2} \mathrm{Al}_{3}\right.$ type orthorhombic), $\mathrm{HfAl}_{2}\left(\mathrm{C} 14, \mathrm{MgZn}_{2}\right.$-type hexagonal), $\mathrm{BHfAl}_{3}\left(\mathrm{DO}_{23}, \mathrm{ZrAl}_{3}\right.$-type tetragonal), and $\alpha \mathrm{HfAl}_{3}\left(D 0_{22}\right.$, $\mathrm{TiAl}_{3}$-type tetragonal). The $\mathrm{Al}-\mathrm{Zr}$ phase diagram [Massalski2] depicts the following intermediate phases: $\mathrm{Al}_{3} \mathrm{Zr}$ ( $D 0_{23}$-type tetragonal), $\mathrm{Al}_{2} \mathrm{Zr}\left(C 14, \mathrm{MgZn}_{2}\right.$-type hexagonal), $\mathrm{Al}_{3} \mathrm{Zr}_{2}\left(\mathrm{Al}_{3} \mathrm{Zr}_{2}\right.$-type orthorhombic), $\mathrm{AlZr}\left(B_{f}\right.$, CrB-type orthorhombic), $\mathrm{Al}_{4} \mathrm{Zr}_{5}$ ( $\mathrm{Ga}_{4} \mathrm{Ti}_{5}$-type hexagonal), $\mathrm{Al}_{3} \mathrm{Zr}_{4}$ ( $\mathrm{Al}_{3} \mathrm{Ir}_{4}$-type hexagonal), $\mathrm{Al}_{2} \mathrm{Zr}_{3}\left(\mathrm{Al}_{2} \mathrm{Zr}_{3}\right.$-type tetragonal), $\mathrm{Al}_{3} \mathrm{Zr}_{5}\left(D 8_{m}, \mathrm{~W}_{5} \mathrm{Si}_{3}\right.$-type tetragonal), $\mathrm{AlZr}_{2}\left(B 8_{2}, \mathrm{Ni}_{2} \mathrm{In}\right.$ type hexagonal), and $\mathrm{AlZr}_{3}\left(\mathrm{Ll}_{2}, \mathrm{AuCu}_{3}\right.$-type cubic). In the Hf-Zr system, continuous solid solutions form between $\beta \mathrm{Hf}$ and $\beta \mathrm{Zr}$, and between $\alpha \mathrm{Hf}$ and $\alpha \mathrm{Zr}$.

\section{Phase Equilibria in Al-Rich Alloys}

With starting metals of $99.99 \% \mathrm{Al}, 99.8 \% \mathrm{Hf}$ and $99.8 \%$ $\mathrm{Zr}$, [2010Rok] melted about 30 binary and ternary alloys in

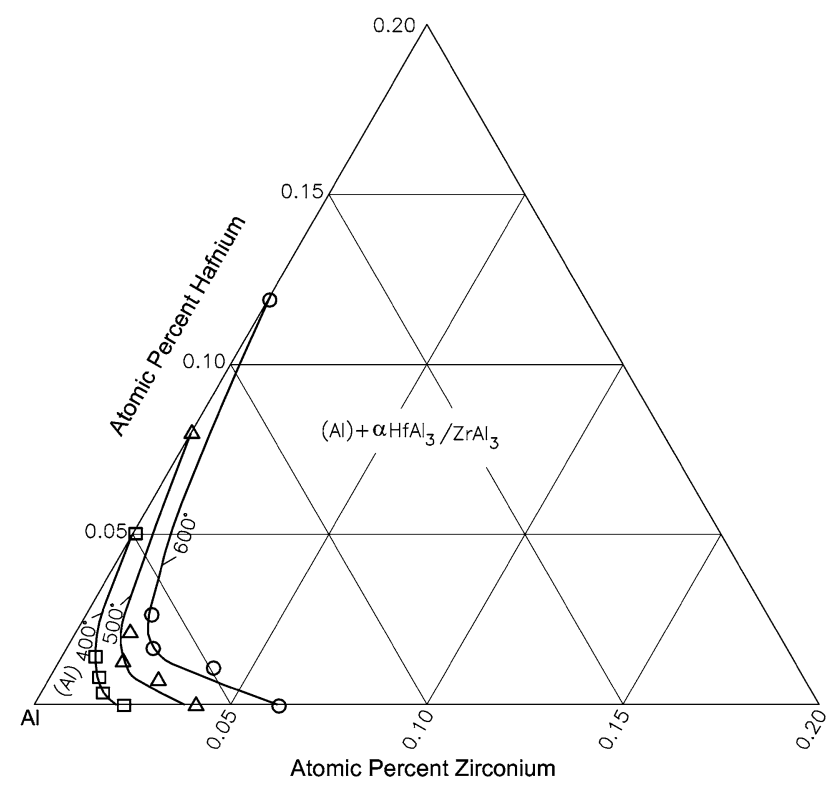

Fig. 1 Al-Hf-Zr solubility limit in (Al) at 600,500 and $400{ }^{\circ} \mathrm{C}$ [2010Rok]

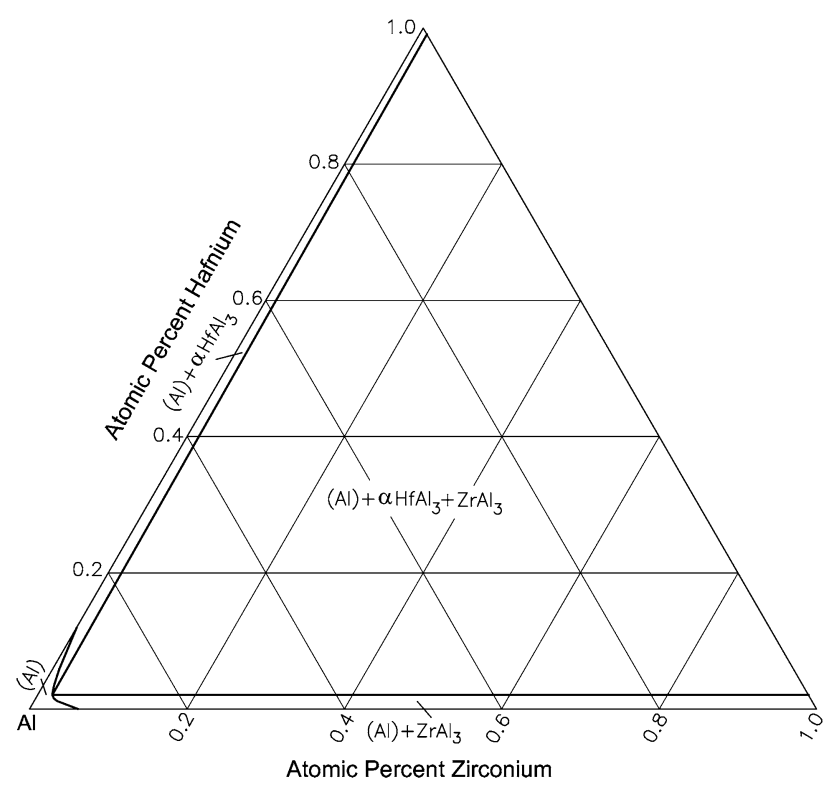

Fig. 2 Al-Hf-Zr isothermal section at $600{ }^{\circ} \mathrm{C}$ near $\mathrm{Al}$ corner [2010Rok]

a resistance furnace, by adding Al-Hf and $\mathrm{Al}-\mathrm{Zr}$ master alloys to an $\mathrm{Al}$ melt. The alloys were given a final anneal at 600,500 and $400{ }^{\circ} \mathrm{C}$ for 30,100 and $100 \mathrm{~h}$, respectively, followed by quenching in water. The phase equilibria were studied with electrical resistivity measurements, optical microscopy and scanning electron microscopy with energy dispersive $\mathrm{x}$-ray analysis. The solubility limits of $\mathrm{Hf}$ and $\mathrm{Zr}$ in (Al) derived from electrical resisitivity measurements at 600,500 and $400{ }^{\circ} \mathrm{C}$ are shown in Fig. 1. The binary compounds $\alpha \mathrm{HfAl}_{3}$ and $\mathrm{ZrAl}_{3}$ are in equilibrium with (Al). Figure 2 shows the isothermal section at the $\mathrm{Al}$ corner at $600{ }^{\circ} \mathrm{C}$ [2010Rok]. The sections at 500 and $400{ }^{\circ} \mathrm{C}$ (not shown here) are similar to the one in Fig. 2 [2010Rok].

\section{References}

1998Mur: J.L. Murray, A.J. McAlister, and D.J. Kahan, The Al-Hf (Aluminum-Hafnium) System, J. Phase Equilib., 1998, 19(4), p 376-379

2010Rok: L.L. Rokhlin, N.R. Bochvar, J. Boselli, and T.V. Dobatkina, Investigation of the Al-Rich Part of the Al-Zr-Hf Phase Diagram for Solid State, J. Phase Equilib. Difffus., 2010, 31(6), p 504-508 